\title{
Jan Beneken (1934-2021): European modeling and simulation pioneer
}

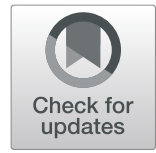

Willem L. van Meurs ${ }^{*}$ (D) and Timothy A. J. Antonius ${ }^{2}$

\begin{abstract}
This obituary highlights a number of contributions by Professor Jan Beneken (1934-2021) to modeling of human physiology and pharmacology and to simulation-based training.
\end{abstract}

Keywords: Obituary, Modeling, Simulation

\section{Background}

European modeling and simulation pioneer Professor Jan Beneken, born in Arnhem, The Netherlands on 20 March 1934, passed away in Eindhoven, The Netherlands, on 23 September 2021. This obituary focusses on the impact of Dr. Beneken on simulationbased training, established via his groundbreaking research on modeling of human physiology and pharmacology, via his mentorship of the team at the University of Florida that invented the Human Patient Simulator, and via the recent Jan Beneken conferences.

\section{Career overview}

Dr. Beneken obtained his electrical engineering degree from the University of Delft, The Netherlands, in 1958, and his $\mathrm{PhD}$ in mathematics and natural sciences from the University of Utrecht, The Netherlands, in 1965. After working for the Netherlands Organization for Applied Scientific Research, he became a full-time professor of Medical Electrical Engineering at the Technical University, Eindhoven, The Netherlands, and served in that function from 1973 until 1995. He was the dean of the Faculty of Electrical Engineering from 1993 until

\footnotetext{
* Correspondence: vanmeurs@orange.fr

${ }^{1}$ Consultant in simulations, 11, Impasse des Balas, 65700 Lahitte-Toupière, France

Full list of author information is available at the end of the article
}

1995. He was the first president of the COMACBME, a coordinating committee of the European Commission for the research area Biomedical Engineering, from 1982 until 1990. He was a co-founder of the European Society for Engineering and Medicine (ESEM), and one of the founders of the journal Technology in Healthcare [1]. In 1995, Dr. Beneken was knighted in the order of the Dutch Lion for exceptional merits to society.

\section{Modeling of human physiology}

His $1965 \mathrm{PhD}$ thesis [2] presents a model that is still used in many simulators today and elaborated upon in many publications; see for example Goodwin et al. [3]. He met American physiologist Arthur Guyton in Leiden, The Netherlands, and was invited to work with him in Jackson, MS in 1965. His 1968 paper with Vincent Rideout, from the University of Wisconsin [4], allows for the coupling of cardiovascular and respiratory models, and his 1972 paper with Ty Smith and Aart Zwart [5] lays the basis for coupling cardiovascular models and models of anesthetic gas transport.

\section{Invention of the human patient simulator}

Drs. Beneken and Joachim (Nik) Gravenstein acted as mentors to the team at the University of Florida that invented the Human Patient Simulator between 1988 and 1994 [6, 7]. Together, they demonstrated how an engineer and a medical specialist could cross the 
boundaries of their respective disciplines and come to highly effective technical solutions to medical problems. Dr. Beneken's specific contributions included acting as a sounding board to the developers of the models of human physiology and pharmacology, which played a major role in making the Human Patient Simulator the most reactive simulator on the market. Dr. Beneken received the University of Florida Distinguished Achievement Award in 1995.

\section{The Jan Beneken conferences}

Two Jan Beneken conferences on modeling and simulation of human physiology took place in Eindhoven, The Netherlands, in 2013, and in Nijmegen, The Netherlands, in 2015. These conferences brought together several generations of Dutch and some other European modelers. Dr. Beneken was actively involved in the organization of the conferences and a stimulating presence during the debates. In 2017, the conference was held at the University of Twente, Enschede, The Netherlands, and with Dr. Beneken's assent renamed to Applied Modeling in Acute Care (AMAC). The broader international coverage of the conferences was confirmed in 2019, when the conference was held in Canberra, Australia. The keynote lecture was given by Nobel prize winner Dr. Brian Schmidt, and Dr. Debra Nestel, Editor in Chief of Advances in Simulation at the time, presented a plenary lecture. Dr. Beneken pre-recorded a brief overview of his career and presented the Jan Beneken award to a promising young modeling researcher from the Australian National University [8] (Fig. 1).

\section{Conclusion}

Via his research on modeling of human physiology and pharmacology, his mentorship of the team that

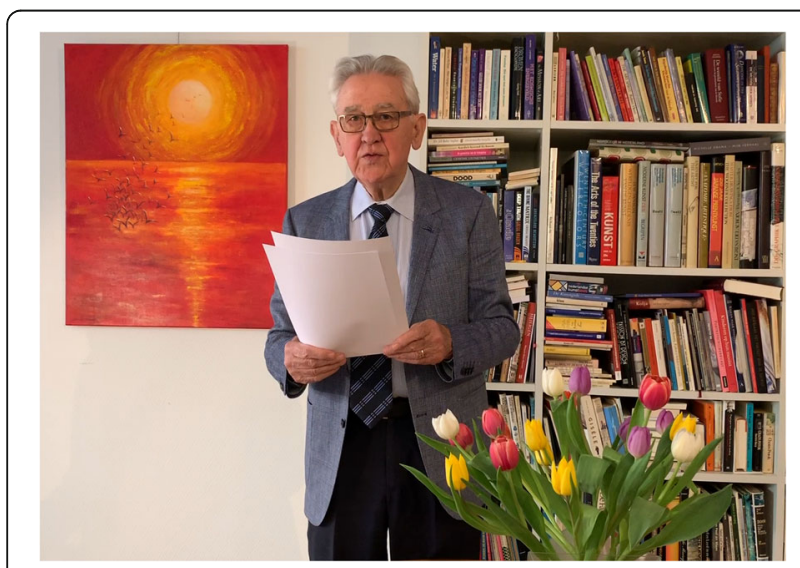

Fig. 1 Dr. Beneken presenting at the 2019 AMAC conference. Reproduced with permission from the video by Dr. Berend Westerhof [9]. Painting in the background: Vrijheid VII ๑ 2009 Gertrude Beneken-Erkelens invented the Human Patient Simulator, and his active participation in the conferences that bear his name, Professor Jan Beneken (1934-2021) made decisive contributions to simulation-based training in Europe and beyond.

\section{Abbreviations \\ AMAC: Applied modeling in acute care; COMAC-BME: Coordinating committee of the European commission for the research area biomedical engineering; ESEM: European society for engineering and medicine}

\section{Acknowledgements}

The authors thank Dr. Beneken's spouse Gertrude Beneken-Erkelens and daughter Margot Beneken for their feedback on the manuscript. They also thank Dr. Berend Westerhof for permission to use the screen shot from the video he recorded.

\section{Authors' contributions}

WvM and TA contributed equally to the manuscript. Both authors read and approved the final manuscript.

Funding

No specific funds were used for this obituary.

Availability of data and materials

An email by Dr. Westerhof giving permission to use the picture is on file.

\section{Declarations}

Ethics approval and consent to participate Not applicable.

\section{Consent for publication}

A letter of consent by Gertrude Beneken-Erkelens, spouse of Jan Beneken, is on file.

\section{Competing interests}

The authors declare that they have no competing interests.

\section{Author details}

${ }^{1}$ Consultant in simulations, 11, Impasse des Balas, 65700 Lahitte-Toupière, France. ${ }^{2}$ Department of Pediatrics, Division of Neonatology, Radboudumc Amalia Children's Hospital, P.O. Box 9101, 6500, HB, Nijmegen, The Netherlands.

Received: 9 November 2021 Accepted: 29 November 2021

Published online: 14 December 2021

\section{References}

1. TU/e Eindhoven University of Technology, Album Academicum. https:// www.emeriti-tueindhoven.nl/prof-dr-ir-jan-e-w-beneken. Accessed 15 Oct 2021.

2. JEW B. A mathematical approach to cardiovascular function: the uncontrolled human system [PhD thesis]. Utrecht: Medisch Fysisch Instituut TNO; 1965.

3. Goodwin JA, van Meurs WL, Sá Couto CD, Beneken JEW, Graves SA. A model for educational simulation of infant cardiovascular physiology. Anest Analg. 2004;99(6):1655-64. https://doi.org/10.1213/01.ANE.0000134797.52 793.AF.

4. Beneken JE, Rideout VC. The use of multiple models in cardiovascular system studies: transport and perturbation methods. IEEE Trans Biomed Eng 1968;15(4):281-9. https://doi.org/10.1109/TBME.1968.4502579.

5. Smith NT, Zwart A, Beneken JE. Interaction between the circulatory effects and the uptake and distribution of halothane: use of a multiple model. Anesthesiology. 1972;37(1):47-58. https://doi.org/10.1097/00000542-1972 07000-00008.

6. Good ML. How the University of Florida's Gainesville Anesthesia Simulator became the Human Patient Simulator. In: Levine Al, DeMaria A, Schwartz $A D$, Sim AJ, editors. The comprehensive textbook of healthcare simulation. New-York: Springer; 2013. p. 24-9. 
7. CAE Products, CAE HPS | The Human Patient Simulator. The Gold Standard in Patient Simulation. https://www.caehealthcare.com/patient-simulation/ hps/. Accessed 15 Oct 2021.

8. Australian National University, College of SCIENCE, News \& events: Designing the healthcare systems of the future, one model at a time. https://science.anu.edu.au/news-events/news/designing-healthcare-systemsfuture-one-model-time. Accessed 15 Oct 2021

9. Westerhof BE. Video of Dr. Beneken's presentation for the 2019 AMAC conference. The Netherlands: Eindhoven; 2019.

\section{Publisher's Note}

Springer Nature remains neutral with regard to jurisdictional claims in published maps and institutional affiliations.

Ready to submit your research? Choose BMC and benefit from:

- fast, convenient online submission

- thorough peer review by experienced researchers in your field

- rapid publication on acceptance

- support for research data, including large and complex data types

- gold Open Access which fosters wider collaboration and increased citations

- maximum visibility for your research: over $100 \mathrm{M}$ website views per year

At $\mathrm{BMC}$, research is always in progress.

Learn more biomedcentral.com/submissions 